\title{
"THE COKE SIDE OF LIFE": uma análise semiolin- guística de peças publicitárias desencannadas
}

\author{
Rosane Santos Mauro Monnerat \\ (UFF) \\ https://orcid.org/0000-0003-2523-9088 \\ Camilla Ramalho Duarte \\ (UFF) \\ https://orcid.org/0000-0002-9021-4816
}

\section{RESUMO}

O presente artigo tem por finalidade analisar peças publicitárias fictícias, criadas pelo site de humor Desencannes, tentando decifrar quais foram as estratégias linguístico-discursivas elencadas para fazer parte da cena enunciativa, pelos sujeitos desencannados, a fim de fazer com que seus leitores se tornem cúmplices do que foi dito. Para que tal análise se dê, explorar-se-ão alguns fundamentos da Teoria Semiolinguística de Análise do Discurso, proposta por Patrick como é o caso dos conceitos de contrato de comunicação, de visadas discursivas e, ainda, o conceito de pathos, esse último recuperado da tradição aristotélica, visto que a publicidade desencannada pretende causar alguma reação patêmica em seu leitor. Também recorrer-se-á a estudos relativos às publicidades canônicas, propostos por Monnerat (2013, 2003), Carvalho (1996) e Pinto (1997), com a finalidade de demonstrar quais foram as estratégias do discurso publicitário mimetizadas pelo discurso desencannado e quais foram, por outro lado, aquelas colocadas em xeque. Logo, à medida que se analisa o referido discurso, pode-se perceber que se trata de um texto singular, uma vez que desconstrói o universo do sério criado pela publicidade canônica, afinal, quebra paradigmas, desconstrói lugares-comuns e estabelece um novo modo de fazer humor, usando a publicidade.

PALAVRAS-CHAVE: Semiolinguística; Publicidade; Desencannes. 


\section{"THE COKE SIDE OF LIFE": a semiolinguistic analysis of a "desencannes" advertisement}

ABSTRACT

The present work aims to analyze fictional pieces of advertisement created by the humour website Desencannes in order to unravel the linguistic discursive strategies used to take part in the uttered scene by the Desencannes subjects to make their readers accomplices of what was said. Therefore, we will resort to some concepts of the Semiolinguistic Theory of Discourse Analysis coined by Patrick Charaudeau such as Communication Contract and Discursive Targeted and the concept of Pathos, recovered from the aristotelian tradition, because as desencannada advertisement intends to cause some pathetic reaction in its reader. In addition, we use some studies related to canonical advertising, proposed by Monnerat (2013, 2003), Carvalho (1996) and Pinto (1997) with the purpose of demonstrating the mimetized advertising strategies in the Desencannes speech and, on the other hand, show the ones called into question in this process. Therefore, as the speech analysis goes on, it is possible to notice that the corpus here comes to a unique text, once it deconstructs the universe of seriousness of the canonical advertisement because it breaks paradigms, common places and establishes a new way of making humour via advertising. KEY-WORDS: Semiolinguistic; Desencannes; Advertising. 


\section{Introdução}

O presente trabalho tem por objetivo analisar duas peças publicitárias fictícias, criadas por um site de humor de internet, chamado Desencannes, uma vez que, na sociedade capitalista em que vivemos, a publicidade conquistou para si um lugar de destaque, já que é uma das responsáveis por engendrar, nos indivíduos, um desejo quase que inatingível de consumir marcas e, consequentemente, produtos. A partir, então, das relações entre pessoas, marcas e produtos, regidas pelo capital, estudar a publicidade tornou-se fundamental, ainda mais se pensarmos nas estratégias linguístico-discursivas postas em jogo, dentro da cena enunciativa, pelos sujeitos do ato de linguagem, tanto nas publicidades de nosso dia a dia, quanto nas desencannadas.

O consumidor parece, dessa forma, compelido, de maneira irreversível, a comprar, posto que cabe a ele escolher que produtos/marcas levará para casa. No entanto, não é permitido que escolha não comprar, nem que decida não fazer parte desse rito, pois, para ser, é preciso, primeiramente, ter. Existe, nesse universo do consumo, uma "lacuna entre o que a publicidade realmente oferece e o futuro que promete, [o que] corresponde à lacuna entre o que o espectador/comprador sente que é e o que ele gostaria de ser" (PINTO, 1997, p. 42).

Aliás, cabe ressaltar que, no artigo em questão, as peças publicitárias, apesar de se assemelharem às publicidades canônicas, desconstroem o universo do sério em que tais textos estão inseridos, porque colocam em xeque muitas das estratégias usadas pela publicidade tradicional, a começar pelo fato de não terem como objetivo primeiro vender uma marca: querem apenas fazer seu destinatário rir, por meio de quebras de expectativas do leitor, neles causando uma reação patêmica.

As publicidades desencannadas trazem, inclusive, textos que, de alguma maneira, não reforçam o caráter positivo das marcas que propagam, nem singularizam os produtos que vendem, mas que, curiosamente, denigrem a imagem desses produtos e marcas, associando-os ao Fascismo, por exemplo, ou dizendo que não são os campeões de venda, porque existem outras marcas que são melhores e, por isso, as escolhidas pelos consumidores.

Tal tipo de corpus se presta bem a uma análise semiolinguística do discurso. Concordamos com Charaudeau (2011, p. 1), quando declara: “Dize-me qual é teu corpus, eu te direi qual é a tua problemática”. Com 
efeito, um "corpus não existe em si, mas depende do posicionamento teórico a partir do qual ele é considerado" (CHARAUDEAU, 2011, p. 1). Assim, esta pesquisa se desenvolve com base em alguns fundamentos da Teoria Semiolinguística do discurso, tais como os conceitos de contrato de comunicação e de visadas discursivas, uma vez que o discurso empreendido pelo Desencannes estabelece outro contrato de comunicação com seus destinatários e cria peças publicitárias fictícias, elencando para elas outra visada discursiva, que não apenas a de incitação.

É o caso da visada de efeito, que pretende gerar uma reação patêmica em seu leitor, provocando nele, por exemplo, riso, indignação, choque. Por esse motivo, recuperar-se-á o conceito de pathos, da tradição aristotélica, haja vista que as emoções produzidas no e pelo discurso são fruto de uma intencionalidade, afinal, o sujeito comunicante pretende engendrar no outro, seu destinatário, uma reação emocional que não é o sentimento propriamente dito, produzido e comprovado quimicamente.

Já que a publicidade desencannada se aproxima e se afasta das estratégias linguístico-discursivas de que faz uso a publicidade canônica, recorrer-se-á, ainda, aos estudos sobre essa área, feitos por Monnerat (2003; 2013), Carvalho (1996) e Pinto (1997), para que se possa estabelecer em que medida se dá tal afastamento e/ou tal aproximação.

A fim de que as análises e discussões acima mencionadas ocorram, é preciso expandir os conceitos citados e aprofundar algumas noções teóricas.

\section{Eixos Teóricos}

Em um primeiro momento, torna-se imprescindível estender as noções de contrato de comunicação e visadas discursivas, propostas por Patrick Charaudeau (2012, pp. 67-68; 2004, p. 22) em sua Teoria Semiolinguística de Análise do Discurso, lembrando que é necessário que os sujeitos do ato de linguagem se reconheçam como parceiros da troca comunicativa e saibam em que situação de comunicação tal troca se insere.

A situação de comunicação pode ser entendida como um construto, de fora do texto, que dita o caminho que a troca linguageira tomará no discurso dos falantes. É, então, o lugar onde se criam as restrições e as possibilidades que determinam a(s) expectativa(s) dessa troca, que podem, ou não, coincidir em termos de sujeitos sociais e discursivos. As mencionadas restrições e possibilidades são fruto, simultaneamente, da identidade dos parceiros da troca, do local que ocupam na cena enunciativa, da finalidade, chamada, aqui, de visada, com que empreendem a inte- 
ração linguageira, da tematização escolhida e das circunstâncias materiais em que ocorrem.

O contrato de comunicação é, por sua vez, um quadro de cointencionalidades ao qual se reportam os sujeitos do ato de linguagem, a fim de que haja troca comunicativa, existindo, entre eles, um acordo mútuo e prévio que possibilita a interação dos indivíduos, levando em conta as restrições engendradas pela situação de comunicação, já que esta impõe uma série de limitações do que se pode e deve, ou não, dizer, estabelecendo, porém, por outro lado, uma gama de possibilidades de escolha, pautadas na intencionalidade do sujeito, que empreende a mencionada atividade linguageira.

Recorremos, pois, às palavras de Charaudeau (2012, p. 68) para elucidar, de vez, a questão:

“O necessário reconhecimento recíproco das restrições da situação pelos parceiros da troca linguageira nos leva a dizer que estes estão ligados por uma espécie de acordo prévio sobre os dados desse quadro de referência. Eles se encontram na situação de dever subscrever, antes de qualquer intenção e estratégia particular, a um contrato de reconhecimento das condições de realização da troca linguageira em que estão envolvidos: um contrato de comunicação". (CHARAUDEAU, 2012, p. 68).

Visadas discursivas, a seu turno, são compreendidas como uma intencionalidade psico-sócio-linguageira que estabelece o "enjeu" da troca comunicativa, assim como a expectativa dos sujeitos discursivos perante a referida troca. Todavia, para que as visadas atinjam o efeito de sentido pretendido, é fundamental que os sujeitos produtores e receptores alcancem qual(is) dela(s) está(ão) em jogo. Cada situação de comunicação escolhe, dessa forma, uma ou mais visadas, responsáveis pelas expectativas das interações linguageiras, realizadas pelos sujeitos do ato de linguagem.

Tendo como exemplo o discurso publicitário e analisando-o em termos de finalidade da troca, torna-se possível estabelecer que a visada, escolhida pelos sujeitos é, a priori, a de incitação, na qual o "eu" se encontra em posição de "fazer crer" um "tu” que está em posição de "querer acreditar". Em outras palavras, o "eu" quer fazer com que o "tu" creia que o produto, o qual quer vender, tem qualidades extraordinárias que nenhum outro tem e é somente adquirindo tal produto que se tornará beneficiário da ação.

Obviamente, a publicidade, para atingir seu objetivo primeiro, a saber, vender uma marca, faz uso de estratégias de persuasão/sedução, com 
o objetivo de convencer seu público-alvo da singularidade do que vende. Para tal, acaba selecionando uma segunda visada, a de efeito, em que o "eu" se encontra em posição de "fazer sentir" o "tu", que se encontra em posição de "querer sentir". Nessa visada, o "eu” tem por finalidade causar um efeito patêmico em seu destinatário, tornando-o cúmplice do discurso produzido, utilizando-se das estratégias de captação permitidas pela situação de comunicação na qual o ato de linguagem se inscreve.

Cabe ressaltar que os efeitos patêmicos não podem ser confundidos com as emoções propriamente ditas, visto que só existem discursivamente, afinal, são produzidos no e pelo discurso. Assim, podem ser considerados uma categoria de efeito que se opõe à outra e dependerão do universo sócio-cultural no qual o ato de linguagem está inserido. Os efeitos patêmicos, então, seriam visados no circuito externo ao texto, podendo-se concretizar, ou não, dentro do circuito interno. É o que acontece, portanto, quando um sujeito escolhe comprar um determinado produto de uma determinada marca, porque, de alguma maneira, engajou-se no discurso produzido pelo enunciador de um texto, deixando-se comover pelo enunciado verbal e, até mesmo, pelos aspectos não-verbais do texto.

As referidas emoções não são fruto apenas das pulsões ou da irracionalidade nem se inscrevem na ordem do incontrolável, uma vez que trazem consigo um caráter social, capaz de determinar o pertencimento de um indivíduo a um grupo, o que representa a vitalidade de uma consciência coletiva. Logo, deve-se considerar que o grupo conduz a maneira como os sujeitos devem-se comportar, moralmente falando, em termos afetivos e emocionais. Portanto, é possível estabelecer que as emoções, por serem compartilhadas socialmente, fazem parte de um quadro axiológico que as torna mais ou menos passíveis de existir em determinados contextos, haja vista que dependem da aprovação dos indivíduos que compõem o grupo social em questão.

Os efeitos patêmicos ligam-se, ainda, às emoções que são, ao contrário do que o senso comum determina, intencionais, estão ligadas a saberes de crença e se inscrevem em uma problemática de representação social. São intencionais, posto que são emoções produzidas no e pelo discurso e têm como ponto de apoio a racionalidade, o que quer dizer que estão a serviço de um agir para alcançar um objetivo que pode, ou não, ser, de fato, atingido. Portanto, as emoções representam desejos de um ou mais sujeitos, o que as torna, desse modo, subjetivas. 
Tais emoções estão, também, ligadas a saberes de crença, pois não é suficiente que os sujeitos percebam algo e que esse algo venha acompanhado de um saber: é preciso que o sujeito considere que pode-se posicionar e avaliar esse algo, a fim de poder vivenciar ou exprimir certas emoções. Os saberes de crença, então, têm como base uma construção subjetiva, o que faz com que se oponham aos saberes de conhecimento, os quais, por sua vez, baseiam-se em critérios de verdade que são exteriores e independem do sujeito em questão.

Além disso, as emoções devem ser tratadas sob um olhar judicativo, já que se apóiam em crenças partilhadas por um ou mais grupos sociais, cujo respeito e até mesmo o desrespeito a elas pode gerar uma sanção moral da ordem do elogio ou da repreensão. Por isso, é possível afirmar que as emoções podem ser vistas como um tipo de estado mental racional em que qualquer modificação de crença leva, necessariamente, a uma modificação de emoção, do mesmo modo que qualquer modificação de emoção leva a um saber de crença.

Como nos lembra Charadeau (2010, p. 30), pode-se afirmar que:

“i) as crenças são constituídas por um saber polarizado em torno de valores socialmente compartilhados; ii) o sujeito mobiliza uma, ou várias, das redes inferenciais propostas pelos universos de crença disponíveis na situação onde ele se encontra, o que é susceptível de desencadear nele um estado emocional; iii) o desencadeamento do estado emocional (ou a sua ausência) o coloca em contato com uma sanção social que culminará em julgamentos diversos de ordem psicológica ou moral". (CHARAUDEAU, 2010, p. 30).

Saberes de crença e saberes de conhecimento fazem parte do universo das Representações Sociais - elementos cognitivos e ideológicos que impõem aos indivíduos de dada sociedade maneiras de agir (JODELET, 2001, pp. 21-22).

Charaudeau (2008, p.195) afirma que as representações sociais possuem uma tripla dimensão: cognitiva, relativa à organização mental da percepção do mundo; simbólica, que se refere à interpretação feita do mundo real; e ideológica, que atribui valores e crenças aos diversos objetos do mundo real, estabelecendo normas para um dado grupo social. Essas representações definirão as maneiras de ver e de julgar de um grupo social, e, consequentemente, sobredeterminarão as maneiras de dizer desse grupo, com base em seus saberes de conhecimento, também chamados de saberes científicos, e em seus saberes de crença (procedentes de juízos e valores). 
Quando se diz que as emoções são estados emocionais que se baseiam em saberes de crença, pode-se dizer, também, que se inscrevem em uma problemática de representação, uma vez que provêm de um duplo movimento de simbolização e de auto-representação. A simbolização acontece enquanto as emoções arrancam os objetos do mundo, fazendo com que deixem de ser objetos e passem a ser uma imagem que parece o objeto, contudo, não é o objeto em si. A noção de auto-representação, a seu turno, acontece, porque o sujeito constrói, imaginariamente, um mundo que, por conta de um fenômeno de reflexividade, retorna ao próprio sujeito como imagem que ele construiu desse mundo e por meio da qual ele mesmo se define. Ou seja, o mundo é auto-apresentado para o sujeito e é por meio de tal imagem que o indivíduo constrói sua identidade, revelando mais sobre si mesmo quando enuncia do que sobre seu enunciado.

As emoções, das quais resultam os efeitos patêmicos, possibilitam que os sujeitos se engajem em um comportamento reacional, de acordo com as normas sociais às quais se submetem e são submetidos, permitindo, assim, que haja um processo de captação para que o destinatário se torne cúmplice e não adversário, aderindo ao que foi dito, sem quaisquer discordâncias ou desentendimentos.

Por outro lado, para que o mencionado processo de captação aconteça, segundo Pinto (1997, p. 11), é necessário que produtos e marcas se insiram em um feixe de relações simbólicas, capazes de fazer com que os objetos mais ordinários se tornem extraordinários, posto que cria, para eles, um valor também simbólico, que é transferido àquele que consome determinado produto/marca. Explica-se: é como se o indivíduo incorporasse tudo aquilo que produtos e marcas têm de bom e admirável.

Vale ressaltar, ainda, que tal processo de sedução/captação ocorre por meio de uma linguagem persuasiva, responsável por convencer as pessoas a investirem seu dinheiro em produtos de que, muitas vezes, não precisam ou dos quais não fazem uso. Logo, "a publicidade é também uma linguagem propriamente dita, feita de palavras que seduzem ou devem seduzir, pelas combinações em que se apresentam, pelas desconstruções que praticam, pelos ecos que despertam, pelos implícitos que activam, por uma série de jogos (...)" (PINTO, 1997, p. 11)

É importante observar, também, que a palavra usada pelo discurso publicitário deixa de ser meramente informativa, pois aparece repleta de significados, os quais reforçam a ideia de que há uma força sedutora e persuasiva nesses vocábulos, o que faz com que, de maneira explícita 
ou implícita, consigam captar seu destinatário para que ele só compre tal marca e, principalmente, para que se integre à sociedade de consumo, tornando-se um consumidor assíduo. Tal integração, na realidade, não ocorre de maneira completa, pois, assim que adquire um bem de consumo, o sujeito continua frustrado, afinal, sua vida é a mesma de sempre, apesar de ter aderido ao que foi trazido pelo discurso publicitário como solução para todos os seus problemas.

Dessa forma, como nos lembra Carvalho (1996, p. 22), "as palavras, em resumo, não exprimem as coisas, mas a consciência que temos delas (...) no caso da publicidade, a palavra não leva à descoberta do eu interior, mas à descoberta dos desejos e aspirações de um tu novo, que ela sedutoramente se propõe a realizar". (ANDRADE, 1992, apud CARVALHO, 1996, p. 22)

A propósito, cabe esclarecer que a publicidade não vende produtos, mas, sim, marcas, o que se pode comprovar se pensarmos no fato de que produtos que não têm marca conhecida vendem muito menos do que aqueles que são de marcas famosas em nosso dia a dia. Desse modo, a marca confere ao produto uma forma de ser e estar no mundo, pois cria, para ele, um valor de referência por meio de comparações; confere, também, uma realidade psicológica - diferente daquela material que o produto/marca carrega consigo -; e uma imagem repleta de conteúdo e carregada de afetividade. Em primeiro lugar, a função da marca é particularizar o produto e, em seguida, mobilizar reações afetivas por parte dos leitores, a fim de estabelecer, entre eles e a marca, um vínculo de fidelidade. Acontece que “o próprio nome se superpõe à generalidade do nome comum, não apenas pela passagem do não-nomeado (no sentido do anônimo) ao nomeado, mas, sobretudo, pela passagem do realismo da matéria (nome comum) ao simbolismo da pessoa (nome próprio)". (Monnerat, 2003, p. 60).

Depois de o presente artigo ter sido ancorado teoricamente, procuraremos desvendar as estratégias linguístico-discursivas de que faz uso o Desencannes.

\section{As estratégias linguístico-discursivas de uma pu- blicidade que não vende}

Como bem se sabe, as peças publicitárias, criadas pelo site Desencannes, não foram feitas com o intuito de vender um produto, uma vez que são fictícias. Contudo, parecem ter como finalidade causar um efeito patêmico em seu destinatário, por meio do riso ou do choque, 
deixando de lado o objetivo primeiro, comum a todas as publicidades: aumentar as vendas de uma marca.

Dessa maneira, é possível estabelecer que a visada escolhida pelos sujeitos enunciadores desencannados é, à primeira vista, diferente daquela elencada pelos sujeitos enunciadores das publicidades canônicas. Explica-se: nesta, os sujeitos precisam persuadir seus destinatários a comprar determinadas marcas, por isso, utilizam a visada de incitação, já que querem fazer com que o outro tome uma atitude e se engaje no discurso veiculado, adquirindo um produto de determinada marca. Já naquela, em realidade, os sujeitos enunciadores desencannados têm a intenção de fazer rir seus destinatários, por isso, deixam de lado a visada de incitação e passam a usar a de efeito, objetivando, assim, que seu destinatário tenha uma reação patêmica diante do enunciado e não que seja compelido a adquirir um produto.

Desse modo, pode-se afirmar que se trata de um efeito patêmico diferente daquele que provocam as propagandas tradicionais, já que o destinatário deixa de ser captado no sentido de ser compelido a comprar determinado produto de determinada marca e passa a ser tragado pelo discurso do Desencannes para que ria ou até mesmo estranhe e se choque com o que está sendo dito, como acontece, por exemplo, quando ele se depara com uma propaganda que responde à outra, haja vista que isso não acontece comumente em nosso país.

Portanto, os sujeitos enunciadores do Desencannes parecem se utilizar de um jogo de luz e sombra em relação às duas visadas acima mencionadas, visto que todo discurso tem como fim a persuasão de seus destinatários, tornando-os cúmplices do que foi dito, ainda que essa não seja a finalidade primordial do Desencannes, o qual pretende fazer seu destinatário reagir ao discurso de maneira diversa.

Se houve uma mudança na visada escolhida para nortear toda a troca linguageira, é possível estabelecer que a situação de comunicação também mudou, posto que as condições de produção de determinado discurso foram, também elas, modificadas. Assim, se a situação de comunicação foi alterada, inevitavelmente, o mesmo acontecerá com o contrato de comunicação, uma vez que o quadro de referência ao qual se reportam os sujeitos do ato de linguagem foi transmutado.

Toda troca linguageira é, então, sobredeterminada por um contrato de comunicação, acordo mútuo e prévio de que fazem parte os parceiros e os protagonistas do ato de linguagem. É ele que diz, por exemplo, que 
as peças publicitárias desencannadas não podem ser entendidas como peças criadas por agências de publicidade de nosso cotidiano, já que foram construídas com outro objetivo, diferente do que é visado por uma publicidade comum. Logo, o intuito do site é possibilitar que o leitor ria ou mesmo se choque ao se deparar com as peças publicitárias desencannadas, quebrando, assim, o enjeu, no dizer de Charaudeau (2004, p. 26), do destinatário de uma propaganda.

Vale lembrar que, na Teoria Semiolinguística de Análise do Discurso, há quatro sujeitos que empreendem o ato de linguagem, sendo dois deles os parceiros e os outros dois os protagonistas. Por parceiros, entendem-se os sujeitos que estão no circuito externo ao texto e que são seres dotados de uma identidade biopsicossocial, ou seja, trata-se do eu comunicante e do tu interpretante; já os protagonistas são o eu enunciador e o tu destinatário, que estão no circuito interno ao texto e são seres do dizer, pois só existem discursivamente.

É mister ressaltar, ainda, que, quando um sujeito credita um status de verdade a uma publicidade desencannada, rompe o contrato de comunicação que foi estabelecido, previamente, pelos parceiros do ato de linguagem, no circuito externo ao texto, uma vez que se reporta a um quadro de referência diverso daquele almejado pelo parceiro da atividade linguageira. Desse modo, pode-se dizer que o acordo foi quebrado, visto que não houve ajuste da margem de manobra, que delimitava o referido contrato.

Torna-se necessário, neste ponto do trabalho, trazer exemplos concretos de publicidades desencannadas para analisá-las, a partir dos eixos teóricos aqui desenvolvidos. 


\subsubsection{Tomando uma Coca-Cola com o Desencannes}

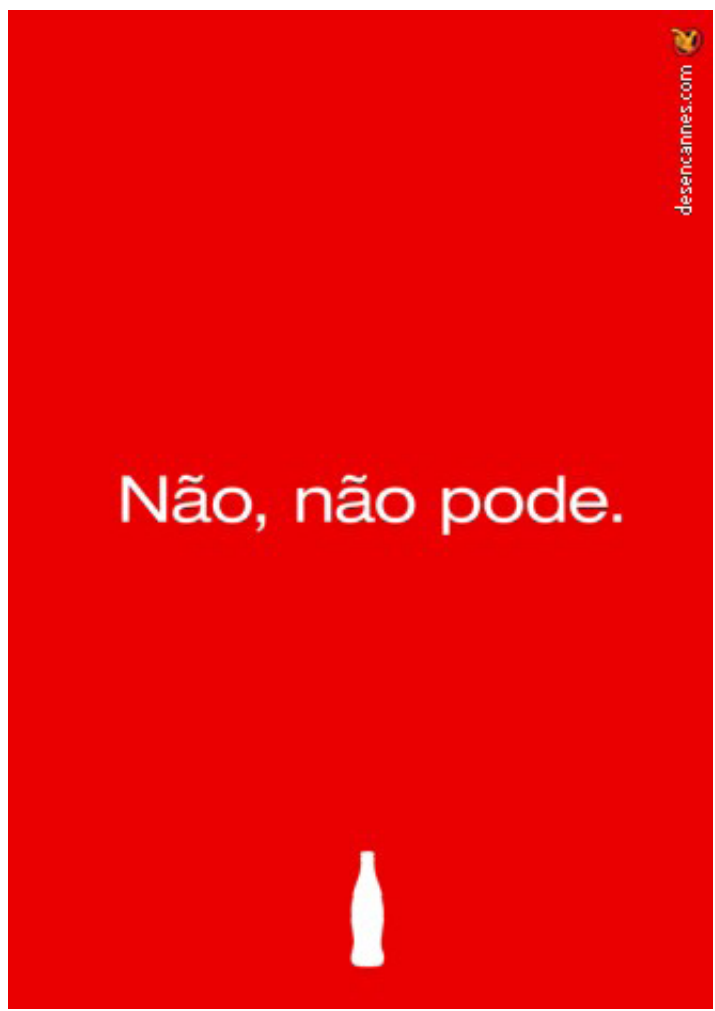

Figura 1 - Peça publicitária da Coca-Cola

Fonte: Site Desencannes.

A peça 1 pode ser considerada singular se levarmos em conta algumas das escolhas linguísticas e discursivas do sujeito enunciador desencannado. Em primeiro lugar, não houve, ao contrário do que acontece no discurso publicitário canônico, uma menção ao nome da marca que está sendo promovida. No entanto, há algumas referências explícitas a ela, como é o caso da cor vermelha, predominante no anúncio, e do uso de uma determinada garrafa para compor a imagem 1 , que fazem com que o destinatário perceba que se trata de uma propaganda fictícia da Coca-Cola, no momento em que ativa uma rede de conhecimentos de mundo que possui, como ser competente. 
Uma das regras basilares da publicidade tradicional talvez seja o uso do nome da marca. O nome Coca-cola, por sua vez, confere identidade psicológica e social ao produto, a fim de que os consumidores o tenham sempre em mente, como é o que ocorre logo que um sujeito se depara com a cor vermelha e o formato da garrafa desse refrigerante e, rapidamente, associa esses dois símbolos, ao nome Coca-Cola. É possível pensar, então, que as outras marcas não são identificadas pelos seus nomes, já que não têm a mesma notoriedade do refrigerante de cola mais vendido do país, mas sim por aquilo que não são: Coca-Cola.

Possivelmente, o destinatário, ao ler o texto em questão, dar-se-á conta de que se trata de uma peça publicitária da Coca-Cola não só por conta da predominância da cor vermelha e do uso da garrafa, mas também por causa do diálogo que existe entre o enunciado verbal, a saber, não, não pode, e um dos filmes promovidos pela marca rival, a Pepsi, como forma de angariar mais consumidores e incrementar as vendas.

O filme da concorrente, a seu turno, mimetizava uma situação bastante corriqueira: pessoas fazendo refeições em um restaurante, onde um garçom aparecia para anotar os pedidos dos clientes que solicitavam outro refrigerante que não Pepsi, ao que o funcionário do estabelecimento respondia Só tem Pepsi, pode ser? Nessa cena enunciativa, os clientes aceitavam a sugestão do homem e escolhiam Pepsi, visto que não havia outra opção, porém, o mesmo não acontece na peça publicitária desencannada, que nega duplamente a sugestão para que se escolha Pepsi, mostrando que só há a possibilidade de o destinatário escolher Coca-Cola.

Todavia, esse procedimento de uma marca responder à sua concorrente não é permitido pelas regras que regem as propagandas feitas no Brasil, o que só pôde ser realizado por se tratar de uma peça publicitária irreal. Assim, a resposta da publicidade para a pergunta feita no comercial da Pepsi fere os princípios que regulam as "boas normas de convivência" das agências de publicidade brasileiras.

Vale ressaltar, ainda, que o sujeito enunciador desencannado adota estratégias de captação para convencer seu destinatário a concordar com o discurso que empreende, fazendo-o compartilhar de suas ideias, de suas crenças e de seu próprio discurso. Dito de outro modo: o sujeito enunciador da peça do Desencannes deseja que o tu destinatário partilhe das opiniões que tem, assentindo que não é possível escolher outro refrigerante que não Coca-Cola. Logo, se os protagonistas do ato de linguagem se tornarem cúmplices, não existirá outra escolha possível, porém, caso 
se tornem adversários, outro refrigerante poderá ser escolhido, como é o caso da Pepsi.

A cumplicidade que possivelmente existirá entre o discurso desencannado, seu enunciador e seu destinatário, além de desencadear o efeito patêmico do riso, é capaz de fazer com que esse último adira ao que foi veiculado, nesse caso, concordando com o fato de que não há outra escolha a ser feita, a não ser Coca-Cola. Desse modo, ainda que haja uma gama de possibilidades de escolha, o sujeito destinatário, uma vez que se engajou no discurso, só é capaz de escolher o refrigerante de cola em questão, o que fica patente com a dupla negativa do enunciado não, não pode.

A referida escolha está, por sua vez, ligada a saberes de crença, posto que não há, na peça 1 , menção a saberes de conhecimento: nenhuma das qualidades intrínsecas que o refrigerante pode possuir é exaltada na figura, logo, parece haver uma crença de que a Coca-Cola é o melhor refrigerante a ser escolhido. Dessa maneira, o sujeito é implicado em um comportamento reacional que o faz optar pela Coca-Cola, o que, por sua vez, faz com que o efeito patêmico se encaixe em um quadro de racionalidade, haja vista o axioma estabelecido em relação à marca e ao produto em questão.

Os saberes de crença, por serem construídos e compartilhados socialmente, são trazidos à baila quando se quer estabelecer um juízo de valor sobre determinado produto de determinada marca, mostrando, desse jeito, que não é possível deixar de se escolher Coca-Cola. Tal escolha, ainda, inscreve-se num quadro de auto-representação que diz mais sobre quem faz tal escolha do que sobre a escolha propriamente dita. Explica-se: posto que se estabelece um juízo de valor positivo no que tange à Coca-Cola, todo o status conferido à marca é, automaticamente, transferido àquele que opta por essa marca, em detrimento de outras, fazendo com que o consumidor adquira todas as qualidades positivas desse refrigerante de cola.

Por fim, ainda que seja uma publicidade às avessas, a figura 1 se utiliza de uma das estratégias de captação do discurso publicitário, a saber, a singularização de um produto para desenvolver seu fazer persuasivo: convertendo, também, o ordinário em extraordinário, o Desencannes afirma que não há outro refrigerante igual à Coca-Cola, dentro do mercado, visto que o destinatário não pode nem deve escolher outra marca, o que a singulariza no meio das demais. 
Parece que já nos detivemos bastante nesta peça publicitária 1 , por esse motivo, passemos à análise de uma nova peça, a da Barilla.

\subsubsection{Barilla: onde tem fusilli, tem Itália}

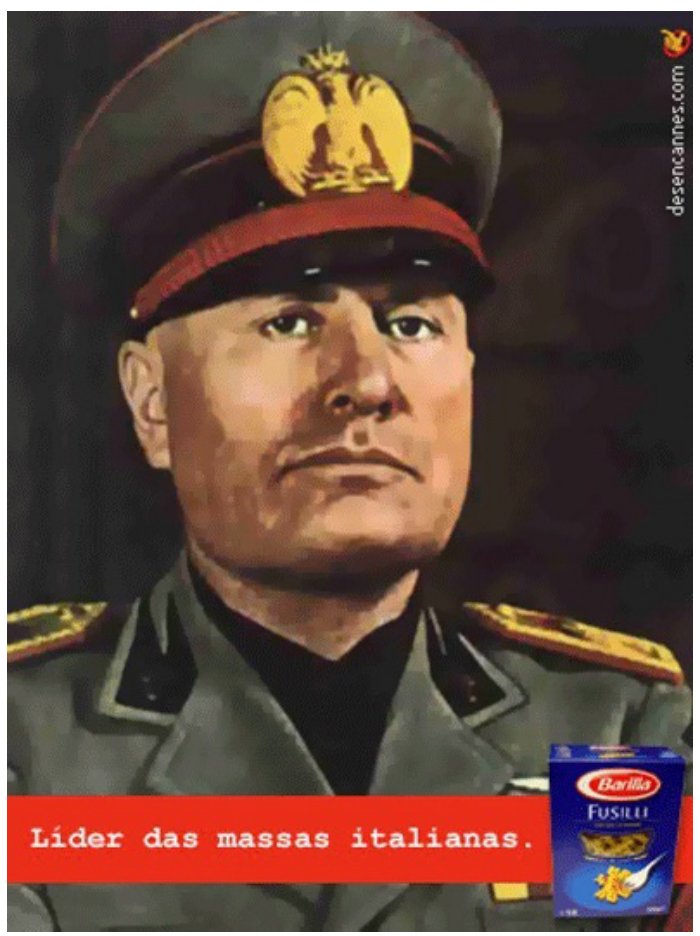

Figura 2 - Peça publicitária do macarrão Barilla.

Fonte: Site Desencannes.

A peça publicitária em destaque rompe com uma das principais estratégias colocadas em jogo, dentro da cena enunciativa, pelos sujeitos enunciadores das publicidades de nosso dia a dia, a saber, realçar as qualidades reais ou simbólicas de seus produtos. Com efeito, percebe-se que o ato de denegrir a marca acontece, já que se associa a massa fusilli, da marca Barilla, à figura de Benito Mussolini, líder do regime fascista, na Itália, que ficou conhecido por conta do totalitarismo, da violência com que tratava seus opositores e pelo fato de que perseguia minorias, como fazia, também, por exemplo, Hitler, na Alemanha. 
Assim, de acordo com o senso comum, é possível imaginar que nenhum publicista escolheria associar a marca que propaga a uma personalidade tão negativa da história da humanidade, contudo, como se trata de uma peça publicitária fictícia, tal escolha é possível, sem que haja prejuízos à imagem da marca ou ao seu número de vendas. É importante deixar claro, entretanto, que o fato de a imagem da marca sair ilesa só acontecerá caso o destinatário perceba que está diante de uma publicidade falsa, que não foi encomendada pelos representantes da Barrilla.

Se se pensar, agora, apenas no enunciado verbal que a publicidade veicula, a saber, líder das massas italianas, perceber-se-á que ele carrega um duplo sentido, haja vista que o líder das massas italianas pode ser tanto Benito Mussolini - o que fica ainda mais evidente por conta da linguagem não-verbal, ou seja, da foto do ditador - quanto o macarrão Barilla, líder de vendas, já que é um produto de qualidade, característica intrínseca aos macarrões italianos.

Há, ainda, outra referência ao contexto de violência e guerra tão comum ao Fascismo: trata-se do uso do vocábulo fusilli para indicar o tipo de massa de que fala a propaganda. No Brasil, tal macarrão é conhecido como "parafuso", todavia, a escolha pelo termo em italiano que, em português, remete à palavra fuzil, por conta da sonoridade, reforça a ideia de que há um duplo sentido no enunciado verbal mencionado.

Vale dizer que é bastante possível que o aspecto icônico do anúncio, a imagem de um militar, chame a atenção do receptor e, provavelmente, provoque nele um estranhamento. Logo, para que se produzisse o efeito de sentido pretendido pelo enunciador, seria necessário que o destinatário usasse seus conhecimentos de mundo e se lembrasse de que a Itália viveu o regime do Fascismo e, em um insight, chegasse à conclusão de que a figura, na realidade, é uma fotografia de Mussolini, quando jovem. Seria exigido, portanto, desse sujeito, que ele partilhasse os saberes enciclopédicos do enunciador da peça, a fim de que o efeito de sentido visado correspondesse ao produzido.

É importante mencionar que, por outro lado, se o destinatário não fizer uso dessa rede de inferências, a propaganda passará despercebida por ele, como sendo apenas mais uma propaganda do ramo alimentício, tão comum em nosso dia a dia. Portanto, o diferencial da peça publicitária desencannada está, também, em todos os conhecimentos que traz e que, de certo modo, exige que seus receptores partilhem. Assim sendo, os destinatários de tal peça são cooptados a não fazer uso da marca Barilla, já 
que isso não lhes renderá nenhum benefício: pelo contrário, resultará em perda de status por conta da associação de imagens que pode ser feita.

Os imaginários sociodiscursivos, por sua vez, também estão presentes no anúncio em questão, já que este veicula representações sociais que engendram saberes de conhecimento e de crença. Ressoam, portanto, na referida peça, dois imaginários conflitantes: o primeiro diz respeito à excelência dos italianos na preparação de massas. Desse modo, caso se considere o vocábulo em seu caráter denotativo, parecerá que o enunciador faz uma ode à aquisição dos produtos da marca Barilla, conforme é o caso do fusilli, já que ninguém seria responsável por fazer massas melhores do que uma marca italiana. $\mathrm{O}$ segundo imaginário evoca o quanto o regime ditatorial fascista foi prejudicial aos italianos e, até mesmo, ao resto do mundo, por esse motivo, quando a massa Barilla é associada à figura desse líder, deve ser descartada como possibilidade de aquisição e consumo, posto que os indivíduos, via de regra, não quererão consumir um produto/marca com a cara de Mussolini.

Nesse momento, torna-se necessário destacar as estratégias de patemização escolhidas pelo sujeito enunciador desencannado, com o objetivo de engajar seu destinatário no que está sendo dito, fazendo com que ele compartilhe de um comportamento reacional, permitindo, assim, que compre um produto de um marca específica.

O sujeito enunciador, portanto, aposta que os conhecimentos de mundo do seu destinatário serão capazes de fazer com que este se perceba diante de uma publicidade às avessas, que não tem por objetivo primeiro vender um produto. Ou seja, o efeito patêmico visado só será atingido se os conhecimentos enciclopédicos partilhados pelos protagonistas do ato de linguagem forem similares, uma vez que, caso isso não ocorra, o destinatário tornar-se-á adversário do referido discurso.

Assim, a atitude de engajamento visada pelo enunciador pretende que o destinatário se torne cúmplice do discurso, optando por não comprar o macarrão da massa Barilla. Essa atitude de engajamento, obviamente, é diversa daquela pretendida por uma propaganda tradicional, ainda que a peça desencannada faça uso de argumentos e saberes de crença que possibilitam a aderência ao discurso em questão. Portanto, apesar de os enunciadores - tanto de propagandas desencannadas quanto de publicidades canônicas - fazerem uso de estratégias patêmicas e, inclusive, de argumentos e saberes de crenças similares, os objetivos com que põem em prática essas maneiras de cooptar o adversário são contrários: 
um sujeito, o enunciador do discurso canônico, almeja persuadir seu destinatário a comprar determinados produtos; o do discurso desencannado, por outro lado, quer dissuadir seu destinatário no que tange a adquirir um produto dessa marca.

Nesse sentido, é possível estabelecer que cabe ao sujeito, como dito, se engajar em um comportamento reacional no qual sairá da inércia e tomará uma atitude com relação ao produto alvo da publicidade. Se as estratégias empreendidas pelo sujeito enunciador do Desencannes forem bem sucedidas, o consumidor repelirá a massa da marca Barilla e optará por outra. Contudo, se o consumidor não aderir à propaganda, adquirirá a marca, ainda que corra o risco de ter sua imagem ligada à de Mussolini e, consequentemente, à do Fascismo.

A escolha desse sujeito destinatário inscreve-se, ainda, em um quadro de auto-representação, em que a referida escolha diz mais sobre quem escolhe do que sobre a marca. Em outras palavras: a partir do momento em que se estabelece um juízo de valor em relação à determinada marca, todo esse status que o produto carrega consigo acaba por ser, automaticamente, transferido para o sujeito que dele faz uso. O contrário também ocorre: aqueles que não adquirirem determinados produtos serão, via de regra, excluídos do universo de consumo e marginalizados por conta dessa impossibilidade de comprá-los.

Todavia, no que diz respeito à peça publicitária 2, a escolha em não consumir a marca cria para o destinatário um status favorável a si mesmo, embora tenha deixado de consumir - o que é praticamente imperdoável no mundo capitalista de hoje -, pois o axioma relativo à massa Barilla apresenta-se como desfavorável à compra, afinal, trata-se de uma marca que teve seu lugar no mundo relacionado à figura de um ditador e, obviamente, não são muitos os que escolhem ter a imagem associada à referida figura.

Muito já foi explanado acerca da peça publicitária do fusilli, da marca Barilla, por esse motivo, cabe, nesse momento, proceder às considerações finais deste artigo. 


\section{Considerações finais}

Por tudo dito anteriormente, pode-se pensar que os diferentes efeitos de sentido, produzidos a partir do discurso desencannado, estão ligados à quebra do contrato de comunicação existente, quando estão em jogo publicidades tradicionais. Explica-se: quando se trata do discurso veiculado pelo Desencannes, esse contrato é posto em xeque, uma vez que existe uma flutuação entre as visadas dominantes: ora se usa a de efeito, ora a de incitação.

Assim sendo, é possível estabelecer que a visada de incitação é, em algum momento, deixada de lado, uma vez que o intuito primordial desse discurso não é fazer seu leitor perceber que precisa de um produto de determinada marca, mas, sim, fazê-lo refletir acerca do fazer publicitário, que arroga para si um status de credibilidade e legitimidade, questionáveis dentro do discurso desencannado. É como se existisse, então, um jogo de claro e escuro que, ora ilumina uma visada, ora deixa outra na escuridão. O intuito de tal atividade linguageira é, portanto, causar um efeito patêmico em seu leitor, fazendo-o rir muitas vezes por meio do estranhamento que causam tais publicidades que seriam impensáveis dentro de um discurso publicitário prototípico.

Nas publicidades às avessas ressoam imaginários e representações sociais, além de saberes de conhecimento e, principalmente, de crença, portanto, é possível estabelecer que o sujeito enunciador do Desencannes apropria-se, muitas vezes, de imaginários sociodiscursivos de nosso mundo real para, assim, estruturar seu próprio discurso. É o que ocorre, por exemplo, na peça publicitária do macarrão da marca Barilla, que tem sua imagem denegrida quando associada à do ditador italiano Benito Mussolini. Ora, é apenas porque o destinatário tem um saber de conhecimento, aliado a um de crença, que essa associação é considerada ofensiva à marca, já que o leitor sabe que o Fascismo foi um dos regimes ditatoriais mais nocivos já vistos no mundo.

Os efeitos patêmicos gerados pelo discurso desencannado têm a ver com a identificação que pode existir entre o discurso veiculado pelo site e seus destinatários. Dito de outro modo: a partir do momento em que os leitores são cooptados por aquilo que as peças publicitárias trazem em termos discursivos, pode-se dizer que houve, de fato, uma espécie de fidelização do destinatário que entenderá as peças como sendo fictícias, já que não vendem um produto e, possivelmente esse leitor se engajará em 
um comportamento racional, capaz de levá-lo a uma reação patêmica, que pode ser, por exemplo, a do riso.

Tais peças impublicáveis aproveitam-se, dessa forma, de estratégias publicitárias tradicionais, reproduzindo-as, transgredindo-as ou extinguindo-as, de acordo com a intencionalidade de seu enunciador. Afinal, como a publicidade, aqui, pode rir de si mesma, acaba-se construindo um discurso em que tudo é possível, menos deixar o destinatário na zona de conforto, como ocorre quando se trata de propagandas canônicas.

\section{REFERÊNCIAS}

CARVAlHO, Nelly de. Publicidade: a linguagem da sedução. São Paulo, Editora Ática, 1996.

CHARAUdEAU, Patrick. Discurso das Mídias. São Paulo, Editora Contexto, 2012.

A patemização na televisão como estratégia de autenticidade. In: MENDES, E. e MACHADO, I. L. As emoções no discurso (vol. II). Campinas, Mercado das Letras, 2010.

Dize-me qual é teu corpus, eu te direi qual é a tua problemática. In:

Revista Diadorim/Revista de Estudos Linguísticos e Literários do programa de Pós-Graduação em Letras Vernáculas da Universidade Federal do Rio de Janeiro, volume 10, dezembro 2011.

Discurso político. São Paulo, Contexto, 2008.

JODELET, Denise. Representações sociais: um domínio em expansão. In: JODELET, D. (Org.). As representações sociais. Rio de Janeiro, EdUERJ, 2001. p.17-41.

MONNERAT, Rosane. O que faz você feliz? Patemização e efeitos de sentido. In: XVII Congresso Nacional de Linguística e Filologia, Rio de Janeiro, CIFEFIL, Cadernos do CNLF, $n^{\circ} 1,2013$.

A publicidade pelo avesso - propaganda e publicidade, ideologias e mitos e a expressão da ideia - o processo de criação da palavra publicitária. Niterói, EdUFF, 2003.

PINTO, Alexandra Guedes. Publicidade: um discurso de sedução. Portugal, Porto Editora, 1997. http://www.desencannes.com.br/. Último acesso em: 24/01/2016. 


\section{ANEXO}

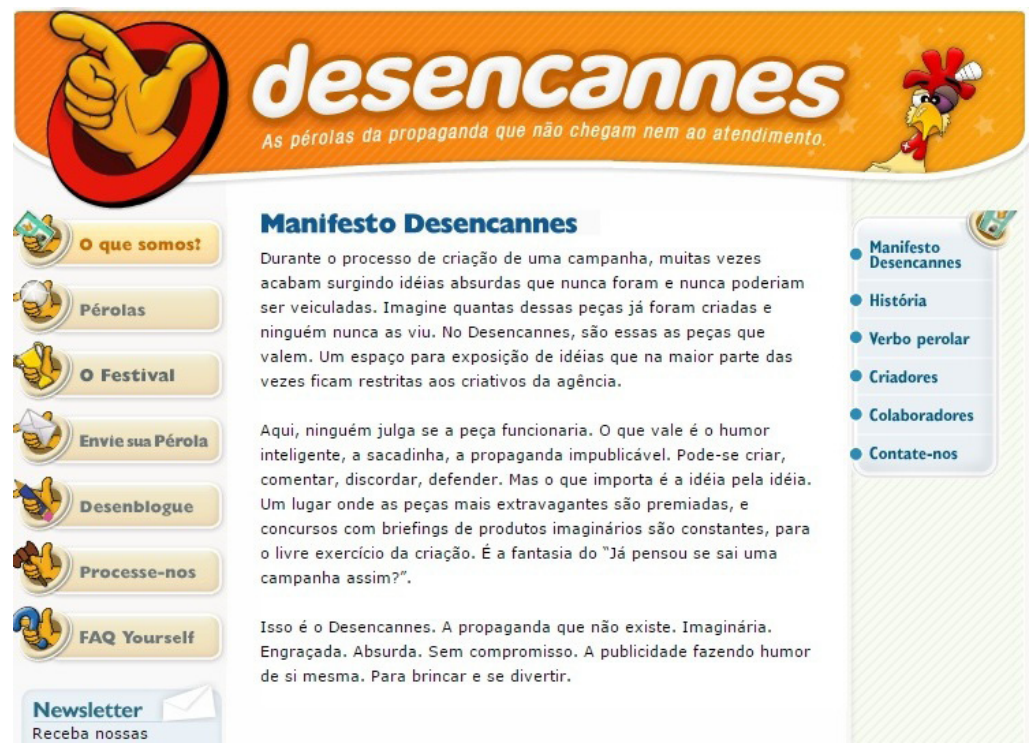

Manifesto Desencannes. Disponível em: http://www.desencannes.com.br/oquesomos/. Acesso em: 05/02/16 